\title{
PROMOTION OF SPANISH SCRIPTED TELEVISION ON THE INTERNET: ANALYZING BROADCAST-RELATED WEBSITES' CONTENT AND SOCIAL AUDIENCE
}

\author{
Promoción de la ficción televisiva española \\ en internet: análisis del contenido de las webs \\ dedicadas a los programas y de la audiencia social
}

Charo Lacalle and Deborah Castro-Mariño

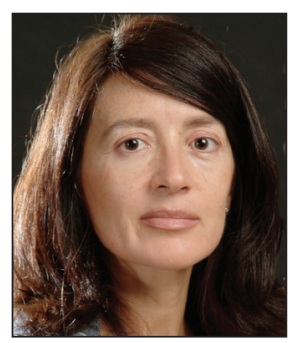

Charo Lacalle is a full professor at the Faculty of Communication Sciences (UAB) where she directs the Department of Journalism. She holds a PhD by the UAB. As a visiting professor, she has taught in several European and Latin American universities. She has numerous publications in books and journals specialized in media communications. She coordinates the Ofent (Observatory of Spanish Fiction and New Technologies) and the Spanish group of Obitel (Ibero-American Observatory of TV Fiction).

http://orcid.org/0000-0002-0024-6591

Autonomous University of Barcelona, Faculty of Communication Sciences 08193 Bellaterra (Barcelona), España rosario.lacalle@uab.es

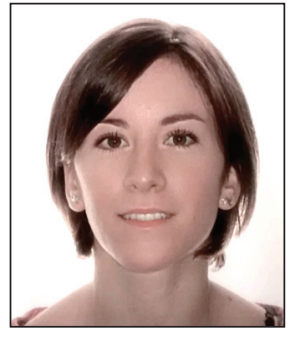

Deborah Castro-Mariño is a post-doctoral researcher at Madeira Interactive Technologies Institute. She holds a PhD in communication studies (Autonomous University of Barcelona, UAB), a M.A. in research in communication and journalism (UAB) and a B.A. in journalism (University of Santiago de Compostela). She was a recipient of the scholarship "Formación de profesorado universitario", offered by the Spanish Government. She is a researcher at the Observatory of Spanish Television Fiction and New Technologies, and at the Ibero-American Observatory of Television Fiction.

http://orcid.org/0000-0001-7980-0964

Madeira Interactive Technologies Institute Caminho da Penteada, 9020-105 Funchal, Portugal deborah.castro@m-iti.org

\begin{abstract}
This article summarizes an investigation into the strategies employed to promote Spanish scripted television (TV fiction) on the Internet. The role of mediation between television networks and their audiences is studied through the content analysis of 515 broadcast-related web sites and 7,849 comments posted by community managers and internet users with assumed feminine digital identities on official and unofficial sites. The official sites are mainly dedicated to providing more information about programs, which represents most of the feedback posted on unofficial sites. Despite extensive activity generated by televised fiction, television networks do not fully exploit these transmedia promotional resources.
\end{abstract}

\section{Keywords}

Web 2.0; Television; Fiction; Promotion; Transmedia; Cultural intermediaries; Scripted television; Spain.

\section{Resumen}

Se resume una investigación sobre las estrategias promocionales de la ficción española en la Red. Se estudia la función de intermediación entre la producción y la recepción, realizada desde las plataformas oficiales y desde las extraoficiales, mediante el análisis de contenido de 515 webs dedicadas a los programas y el análisis de 7.849 comentarios firmados por los community managers y por los usuarios que adoptan identidades digitales femeninas. Las páginas oficiales se dedican principalmente a ampliar las informaciones sobre los programas, que retroalimentan una buena parte de las plataformas no oficiales. A pesar de la enorme actividad generada por la ficción televisiva, las cadenas no explotan suficientemente estos recursos promocionales transmediales. 


\section{Palabras clave}

Web 2.0; Televisión; Ficción; Promoción; Transmedia; Intermediarios culturales; España.

Lacalle, Charo; Castro-Mariño, Deborah (2016). "Promotion of Spanish scripted television on the internet: analyzing broadcast-related websites' content and social audience". El profesional de la información, v. 25, n. 2, pp. $246-253$.

http://dx.doi.org/10.3145/epi.2016.mar.11

\section{Introduction}

The Internet has notably modified the relationship between television and its viewers. In general, television networks tend to adopt a "dominant" position in the digital arena in response to a multimedia environment in constant change (Siapera, 2004, p. 168). Nevertheless, faced with the "colonizing" assault of television companies, understanding and exploiting the peculiarities of each network (Siapera, 2004), and reconfiguring communication with their audiences (Chan-Olmsted; Park, 2000) are key points when designing distinguishing strategies that allow television networks to optimize their resources on the Internet.

The concept of transmedia is generally used to describe the interactions between media contents and their distribution through multiple sites. However, while some authors have examined transmedia processes mainly from the perspective of production (Gillan, 2010; Jenkins, 2006), other researchers have highlighted the transformation of consumers into powerful players positioned "to recognize, distinguish, and combine different genres, media and subject positioning" (Kinder, 1992, p. 47), the new forms of involvement for viewers of audiovisual media (Evans, 2011) and the various forms of collaborative process (Deery, 2003; Siapera, 2004).

\subsection{From television viewer to fan}

Television feedback provided through the Internet transforms the viewer of traditional audiovisual media into a public, both in its sense as a noun (which presupposes socialization) and as an adjective (which underlines the impulse for self-presentation) (Dayan, 2001). Each public is characterized by its "commissive" performance, a concept that Dayan adopts from pragmatics to describe the affirmation of loyalty on the part of its members and to differentiate it from the "almost public" made up of viewers (Dayan, 2001). Nevertheless, "TV websites are continuing a mode of address that is also prevalent offline" (Siapera, 2004, p. 167).

Complementary to the marketing strategies implemented by networks on the Internet (distribution of program information and images, streaming, merchandising, participation by the actors, etc.), the dialogues between fans have cultural, social, and economic implications (Lee, 2012). Gauntlett underlines the role of communities in similarly-themed websites (Gauntlett, 2000, p. 14), while Ramos, Lozano and Hernández-Santaolalla (2012, p. 1221) consider fanadvertising a promotional tool that strengthens a program's brand image. Corujo (2012, p. 142) reminds us that each interaction is important because "it adds up in our audience's mind and affects our reputation".
The emotional and intellectual involvement of viewers with television programs (Jenkins, 1992b) allows us to group them into two opposing profiles: the fan and the anti-fan. The anti-fan shows complete disinterest in the story, which is the result of an interpretation made from the outside (Gray, 2003), whereas a fan likes a show and enjoys it (Siapera, 2004). Digital fans are committed to the story and proclaim their right to interpret, evaluate, and appropriate television programs (Jenkins, 1992b). They are "consumers who also produce, readers who also write, spectators who also participate" (Jenkins, 1992a, p. 208) and opinion generators (Vassallo, 2012) who experience the program dynamically and wish to enjoy it with other internauts (Ramos; Lozano, 2011). The fans are members of a specialized brand community which is "based on a structured set of social relationships among admirers of a brand" (Muniz; O'Guinn, 2001, p. 412). They share their experiences and enthusiasm for a brand, product or activity (Lee, 2012, p. 2) in a context characterized by constant product differentiation and re-qualification (Callon; Méadel; Rabeharisoa, 2002; McFall, 2012).

The introduction of a return channel in TV 2.0 communication has yielded new online promotional mechanisms that complement traditional strategies

\subsection{Fans or cultural mediators?}

Consumption sociology and anthropology have reclaimed Pierre Bordieu's concept of cultural intermediaries $(\mathrm{Cl})$ in order to define "a group of taste makers and needs merchants" (Smith-Maguire, 2014, p. 15) that act as a transmission belt between producers and consumers, creating emotional bonds. It is a complex concept, criticized on occasions for its progressive distancing from Pierre Bordieu's initial formulation (Bordieu, 1979), though it has nevertheless been broadly adopted by academics interested in analyzing Internet-mediated communication (Cronin, 2004; SmithMaguire; Matthews, 2012, p. 11). In the current economy of services, particularly in ICTs, "competition turns around the attachment of consumers to products whose qualities have progressively been defined with their active participation (Callon; Méadel; Rabeharisoa, 2002, p. 212).

In the same vein as authors such as Martínez-Priego (2009, p. 145), who defines the community manager as the missing link between the logotype and the users, or Negus (2002) and Lee (2012), who are interested in determining the dynamics of the mediation, we adopt a broad definition of $\mathrm{Cl}$ that unites the various figures involved in the communication ge- 
nerated by the spread of television fiction to the Internet. It is a concept built around the mediation processes and includes both the community managers of official and unofficial sites and the actors and actresses who participate in the forums and social networks, and even the fans themselves.

\subsection{Controversy over user-generated content}

Investigations into fandom at the end of the 1990s underlined the excitement of a participative culture fostered by media companies through images of empowerment (Jenkins, 1998). However, while the expansion of the Internet increased business opportunities, the high-tech gift economy of the collaborative web moved "from the fringes into the mainstream" (Barbrook, 2005) and shaped its own version of the gift economy without obligation of reciprocity (Kjosen, 2011). The controversy surrounding the boundaries between acceptance and exploitation of user-generatedcontent arouses conflicting opinions. Some authors criticize the promotional exploitation of user-generated products by networks (Russo, 2009). Other investigators, in contrast, distinguish between users' free labor and exploited labor on the basis that much of the former activity is carried out for the mere pleasure of communication and exchange (Terranova, 2000, p. 48).

\section{The controversy surrounding the boun- daries between acceptance and exploi- tation of user-generated-content arou- ses conflicting opinions}

Jenkins, Ford and Green remind us that currently the aims of the commodity culture and gift economy are fully interconnected, and that "all of us operate within an economic context of capitalism" (Jenkins; Ford; Green, 2013, p. 63). In this context, the need of policies aimed at fostering fans' online participation (Preece; Nonnecke; Andrews, 2004) and of collaborationist policies between industry and consumers is presented as an alternative to protectionist policies (Jenkins, 2006). It is the turn of the television networks to harness the enormous potential of transmedia activity -official and unofficial- in a market system "where an increasing number of users are consulting the Internet in search of guidance in their shopping decisions" (Meso-Ayerdi; Mendiguren-Galdospin; Pérez-Dasilva, 2015, p. 386).

This article summarizes the research into the promotional strategies of Spanish scripted television on the Internet and studies the role of mediation between television networks and their audiences. The study, included in a broader investigation into women's reception of Spanish scripted television, examines the format and content of official and unofficial sites dedicated to Spanish scripted television and analyzes the comments posted by community managers and Internet users who signed with feminine names.

The research starts from the following hypotheses:

$\mathrm{H} 1$ : The official sites dedicated to Spanish scripted television mainly focus on the distribution of information about programs.
$\mathrm{H} 2$ : The distribution of contents on unofficial sites and comments on forums and social networks represent promotion strategies for television networks.

H3: Evaluations posted in comments about programs are mostly positive.

H4: Unlike other companies, whose preferred core business strategy is reputation management, television networks do not fully exploit these transmedia strategies.

\section{Method}

In the initial part of the investigation, the contents of 515 sites associated with 72 Spanish television programs active on the Internet in 2013 were analyzed. The sample was derived from the results displayed in the first five pages of two searches on Google.es, filtered to exclude unofficial Facebook pages with less than 1,000 followers, one-off pieces (e.g. a newspaper article) or download pages. The following equation summarizes the process carried out, $N$ being the total number of sites included in the map of Internet resources. First, we define $S^{1}$ as the first Google search ("program title") and $S^{2}$ as the second Google search ("program title" + "television network"). In this way, for the $p^{\text {th }}$ fiction program, we define $S_{p}^{j}$ as the set of sites derived from the $j^{\text {th }}$ Google search that fulfils the stipulated criteria:

$$
N=\sum_{\substack{1 \leq p \leq 72 \\ j=1,2}} n\left(S_{p}^{j}\right)
$$

The 515 sites making up the map of broadcast-related websites were analyzed using a template designed for SPSS, whose 44 variables (41 numeric and 3 string) allow us to break them down, both at the formal level (web format, type of administration, etc.) and content level (audiovisual, interactive, etc.). Alongside the descriptive statistical analysis, a qualitative database was generated, made up of the statistical analysis variables and designed to contextualize the quantitative data obtained, which allowed us to identify the main sites from which to take the phase 2 samples.

Contrary to authors like Askwith (2007), interested in a textual approach of transmediality, the codes designed to be used in this study pursue two goals:

Table 1. Content analysis codebook

\begin{tabular}{|l|l|}
\hline \multicolumn{1}{|c|}{ Category } & \multicolumn{1}{c|}{ Variable } \\
\hline Format & Microsite, social network, forum, blog \\
\hline Specificity & Specific fiction, general fiction, general TV \\
\hline Interactivity & Interactive, non-interactive \\
\hline Accessibility & Open access, registering \\
\hline Type of content & $\begin{array}{l}\text { - Static (images, program fact files, audience } \\
\text { data section, written interviews, etc.) } \\
\text { Interactive (votes, quizzes, games, etc.) } \\
\text { sudionisual (complete episodes, video discus- } \\
\text { the making of, video interviews, etc.) }\end{array}$ \\
\hline Networking & $\begin{array}{l}\text { Links to other sites, synchronization with social } \\
\text { networks }\end{array}$ \\
\hline
\end{tabular}


Table 2. Message analysis codebook

\begin{tabular}{|l|l|}
\hline \multicolumn{1}{|c|}{ Category } & \multicolumn{1}{c|}{ Code } \\
\hline Descriptive codes & \#community manager, \#internet-user \\
\hline Authorship & \#facebook, \#forum, \#twitter \\
\hline Web resource & \\
\hline Narrative world & \#positive-storylines \\
\cline { 2 - 2 } Storytelling Level & \#positive-characters \\
\cline { 2 - 2 } & \#positive-actors/actresses \\
\hline Commodity level & \#promotion, \#audience-data \\
\hline Other & \multicolumn{2}{|l}{} \\
\hline Mobilization & \#petitions \\
\hline Miscellany & $\begin{array}{l}\text { \#references-to-other-programs, \#censorship, } \\
\text { \#congratulations }\end{array}$ \\
\hline
\end{tabular}

1) carrying out a format and content analysis of the map of broadcast-related websites (table 1) and,

2) describing the internet users' feedback towards the TV program, paying special attention to the promotional strategies (table 2).

Hence, the codes displayed in the abovementioned tables are mutually non-exclusive and complementary.

In the second phase of the investigation, the posts published by viewers and community managers on Facebook, Twitter, and the main forums dedicated to the programs were analyzed. According to researchers like Spottswood et al. (2013), usernames and message content are verbal cues employed by Internet users to project their gender. In this way, gender and adjective agreement of the Spanish language, along with the use of usernames (either their real names or nicknames), avatars, and photographs allowed us to distinguish messages signed by internet users with assumed feminine digital identities from the rest.

This selection was carried out by the researchers manually since web crawler tools and data mining programs (like $\mathrm{R}$ programming language), which are available in data analysis packages adapted to different social networks, offered an imprecise approach in terms of identifying internet users' genders. Moreover, the qualitative software Atlas.ti facilitates manual coding and reduces the margin of error typical of traditional coding. The decision to manually code is justified due to linguistic ambiguity both in terms of meaning and significance and also because the brevity of most online posts requires adequate contextualization.

The investigation centres on the analysis of the opinion generated the day after the series' last episode or corresponding season (denoted by "Day $\beta$ "), considered a "significant event" likely to increase participation (Barkhuus; Brown, 2009, p. 13; Larsen, 2010, p. 158). The sample consists of 7,849 units of analysis from 122 sites: 18 Facebook pages; 67 Twitter accounts and 37 forums associated with the programs. In general terms, per program, we collected the last 50 comments posted the day after the last episode in the period of analysis was broadcast $\left(N w_{P}^{i}\right)$ i.e. the last 50 comments posted before 23:59 on Day $\beta$. However, where there were not enough messages, the sample was completed retrospectively to make up the required numbers. $81.5 \%$ $(\mathrm{N}=6,397)$ of the comments collected had been posted by viewers and $18.5 \%(\mathrm{~N}=1,452)$ by community managers. The total number of comments $(N)$ can be simply calculated using the equation:

$$
N=\sum_{\substack{1 \leq i \leq 72 \\ \text { Facebook, } \\ \text { Twitter, } \\ \text { Forums }}} N w_{P}^{i}+N a_{P}^{i}
$$

In the above equation, $\left(N w_{P}^{\iota}\right)$ and $\left(N a_{P}^{\iota}\right)$ are the number of comments collected from website $P$ for the $i^{\text {th }}$ TV series posted by Internet users and administrators, respectively, where $N w_{P}^{i} \leq 50$

The interpretation started once the comments had been categorized (tagging) and the analysis units filtered by code. The promotional strategies analysis codebooks $(\mathrm{N}=14)$ are divided into three sections.

Twitter is the web 2.0 resource most used by the actresses appearing in the programs, who from their personal Twitter accounts invite their followers to watch the program

\section{Results}

Antena3 programs have the greatest number of broadcastrelated websites (35.9\%, M=185 sites), followed by Tele5 ( $21.7 \%, M=112$ sites). $69.9 \%$ ( $M=360$ sites) of the broadcastrelated web sites are associated with a series, $16.9 \%(\mathrm{M}=87$ sites) with a serial, $6.0 \%$ ( $M=31$ sites) with a TV film, 5.0\% ( $M=26$ sites) with a miniseries and $2.1 \%(M=11$ sites) with a sketch. These are interactive resources (97.5\%; $M=502$ sites) that aim to promote programs through the publication of written and audiovisual content.

Microsites form the core of the networks' transmedia strategies (51.8\%; $M=103$ sites), followed by social networks (45.7\%; $M=91$ sites) aimed at increasing web traffic with the posting of links to content created by the microsite and offering space for debate for the fan community. 75.4\% ( $M=150$ sites) of these broadcast-related web sites are closed; in other words, the user is required to register in order to participate. In terms of content, photographs (79.9\%; $M=159$ sites), program fact files (56.8\%; $M=113$ sites), and videos of complete episodes (40.2\%; $M=80$ sites) are the most usual forms. As for the unofficial broadcast-related websites, trailers (34.7\%; $M=69$ sites), best moments $(27.6 \%$; $M=55$ sites), and video interviews ( $17.3 \% ; M=33$ sites) make up the majority of the promotional audiovisual material. The networking of these websites is mainly supported by the inclusion of links to other broadcast-related websites associated with the program (68.3\%; $M=136$ sites).

The microsites (42.4\%; $M=134$ sites) and unofficial social networks (31.3\%; $M=99$ sites) are the formats most com- 
Table 3. Summary of the contents of the websites

\begin{tabular}{|c|c|c|}
\hline & Official & Unofficial \\
\hline Format & $\begin{array}{l}\text { Website }(51.8 \% ; M=103) \\
\text { Social network }(45.7 \% ; M=91) \\
\text { Forum }(1.5 \% ; M=3) \\
\text { Blog }(1.0 \% ; M=2)\end{array}$ & $\begin{array}{l}\text { Website }(42.4 \% ; M=134) \\
\text { Social network }(31.3 \% ; M=99) \\
\text { Blog }(23.7 \% ; M=75) \\
\text { Forum }(2.5 \% ; M=8)\end{array}$ \\
\hline Type & $\begin{array}{l}\text { Specific fiction }(94.0 \% ; M=187) \\
\text { General TV }(4.5 \% ; M=9) \\
\text { General fiction }(1.5 \% ; M=3)\end{array}$ & $\begin{array}{l}\text { Specific fiction }(45.6 \% ; M=144) \\
\text { General TV }(39.9 \% ; M=126) \\
\text { General fiction }(14.6 \% ; M=46)\end{array}$ \\
\hline Interactivity & Interactive $(92.0 \% ; \mathrm{M}=189)$ & Interactive $(99.1 \% ; M=313)$ \\
\hline Accessibility & $\begin{array}{l}\text { Closed }(75.4 \% ; M=150) \\
\text { Content publication }(60.3 \% ; M=120)\end{array}$ & $\begin{array}{l}\text { Closed }(69.0 \% ; M=218) \\
\text { Content publication }(70.3 \% ; M=222)\end{array}$ \\
\hline Content ( $\geq 40 \%$ ) & $\begin{array}{l}\text { Static } \\
\text { Photos }(79.9 \% ; M=159) \\
\text { Fact files }(56.8 \% ; M=113) \\
\text { Audiovisual } \\
\text { Complete episodes }(40.2 \% ; M=80)\end{array}$ & $\begin{array}{l}\text { Static } \\
\text { Photos }(93.4 \% ; M=295) \\
\text { Fact files }(45.9 \% ; M=145) \\
\text { Interactive } \\
\text { Votes }(42.1 \% ; M=133)\end{array}$ \\
\hline \multirow{3}{*}{ Content ( $\leq 40 \%)$} & $\begin{array}{l}\text { Static } \\
\text { Audience section }(0.5 \% ; M=1) \\
\text { Written interviews }(7.5 \% ; M=15)\end{array}$ & $\begin{array}{l}\text { Static } \\
\text { Audience section }(20.9 \% ; M=66) \\
\text { Written interviews }(21.8 \% ; M=69)\end{array}$ \\
\hline & $\begin{array}{l}\text { Interactive } \\
\text { Votes }(21.6 \% ; M=43) \\
\text { Quizzes }(14.1 \% ; M=28) \\
\text { Games }(4.0 \% ; M=8)\end{array}$ & $\begin{array}{l}\text { Interactive } \\
\text { Quizzes }(4.1 \% ; M=13) \\
\text { Games }(3.2 \% ; M=10)\end{array}$ \\
\hline & $\begin{array}{l}\text { Audiovisual } \\
\text { Video discussions }(9.5 \% ; M=19) \\
\text { Best moments }(27.6 \% ; M=55) \\
\text { Trailers ( } 34.7 \% ; M=69) \\
\text { Special videos }(11.6 \% ; M=23) \\
\text { Making of }(15.6 \% ; M=31) \\
\text { Video interviews }(17.3 \% ; M=33)\end{array}$ & $\begin{array}{l}\text { Audiovisual } \\
\text { Video discussions }(0.6 \% ; M=2) \\
\text { Complete episodes }(5.7 \% ; M=18) \\
\text { Best moments }(12.3 \% ; M=39) \\
\text { Trailers }(24.4 \% ; M=77) \\
\text { Special videos }(3.2 \% ; M=10) \\
\text { Making of }(5.4 \% ; M=17) \\
\text { Video interviews }(17.1 \% ; M=54)\end{array}$ \\
\hline Networking & $\begin{array}{l}\text { Links }(68.3 \% ; M=136) \\
\text { Synchronization with social networks }(41.7 \% ; M=83)\end{array}$ & $\begin{array}{l}\text { Links }(37.3 \% ; M=118) \\
\text { Synchronization with social networks }(63.0 \% ; M=199)\end{array}$ \\
\hline
\end{tabular}

monly employed for the promotion of programs, $45.6 \%$ ( $M=144$ sites) of which dedicate space specifically for the program being promoted. $69.0 \%$ ( $M=218$ sites) of these are closed. Photographs (93.4\%; $M=295$ sites), program fact files (45.9\%; $M=145$ sites) and votes (42.1\%; $M=133$ sites) are the most usual content material, while trailers $(24.4 \%$; $M=77$ sites), video interviews ( $17.1 \% ; M=54$ sites), and best moments (12.3\%; $M=39$ sites) are the most popular audiovisual content. The broadcast-related websites are synchronized with social networks (63.0\%; $M=199$ sites) for content distribution.

\subsection{Discursive buzz and promotion}

The 7,849 messages making up the sample generated 22,301 tags $^{1}$ that take the form of a long tail (Anderson, 2008). The resulting form has a "large head", containing references to the storylines, and a "long tail" made up of miscellaneous themes such as the soundtrack, negative comments about the actors, the control of the messages exercised by the websites, etc.

The analysis explores the promotion strategies adopted by community managers and female fans in 5,610 comments, which represent $71.5 \%$ of the total: promotion $(\mathrm{N}=1,390$ posts); references to other programs ( $\mathrm{N}=487$ posts); mobilization ( $\mathrm{N}=825$ posts); positive references to the storyline
( $N=1,297$ posts), to the characters ( $N=597$ posts) and to the actors ( $\mathrm{N}=474$ posts); congratulations ( $\mathrm{N}=307$ posts); audience data ( $\mathrm{N}=229$ posts) and censorship ( $\mathrm{N}=4$ posts).

$62.7 \%$ ( $N=871$ posts) of the promotion-specific comments posted on official sites provide information about future episodes, comment on the latest episode, announce events and include paratextual contents (best moments, complete episodes, etc.), generally on the official microsite. Community managers encourage viewing and the integration of fans into the community. They also mobilize female viewers for viral promotion or participation in the events they are promoting ( $25.5 \%, \mathrm{~N}=210$ posts) and provide audience data (22.0\%, $\mathrm{N}=50$ posts).

Community managers attempt to influence internauts through the positive evaluation of the program $(4.5 \%$, $\mathrm{N}=58$ ), characters $(8.3 \%, \mathrm{~N}=50$ posts), and actors $(4.4 \%$, $\mathrm{N}=21$ posts). Occasionally, they congratulate the community and thank viewers for their support (12.1\%, N=37), a strategy that usually secures a good position on Twitter's trending topic. Moreover, Twitter is the web 2.0 resource most used by the actresses appearing in the programs, who from their personal Twitter accounts invite their followers to watch the program.

$37.3 \%$ ( $\mathrm{N}=519$ posts) of the promotion-specific comments 
published on the unofficial sites remind users the time the next episode is to be broadcast or include links to other sites. Furthermore, in $74.5 \%$ ( $\mathrm{N}=615$ posts) of the comments, the female fans urge mobilization, mainly to stop the program's definitive ending.

Positive references to the storyline mainly come from female fans (95.5\%, $\mathrm{N}=1,239$ posts), as do positive comments about the characters (91.6\%, N=547 posts), and about the actors ( $95.5 \%, \mathrm{~N}=453$ posts). $87.9 \%$ ( $\mathrm{N}=270$ posts) of their comments include felicitations to the network or the technical team. Female fans' commitment is also manifest in the messages about their viewing experiences, in which they compare stories, seasons or episodes of the same series (91.2\%, $\mathrm{N}=444$ posts). At times, the female viewers post audience data (77\%; $\mathrm{N}=176$ posts) to reinforce their opinions.

Finally, the fact that only $0.1 \%$ ( $N=4$ posts) of the comments posted by female users concern censorship by the administrators confirms the generalized adoption of netiquette protocols by female fans.

\section{Discussion and conclusions}

The introduction of a return channel in TV 2.0 communication has yielded new online promotional mechanisms that complement traditional strategies. The networks' official websites usually host an individual microsite for most of their programs (Deery, 2003) that display static content (e.g. announcements), interactive content (e.g. video discussions), audiovisual content (e.g. complete episodes), and provide spaces for discussion (e.g. links to Facebook pages) aimed at fostering viewer loyalty (Ramos; Lozano, 2011). The program format influences its digital distribution, as highlighted by the greater amount of activity generated by series and serials compared to miniseries and TV films (Lacalle, 2013).

The content analysis of official broadcast-related websites highlights the interest of TV networks in satisfying a vast public, which ranges from the not-so-committed female viewers to proactive fans via the "learning audiences" (Siapera, 2004), who are provided informative content (historical, social, etc.). In addition, maintaining activity on social networks, especially Twitter, encourages live viewing, thus favoring the consumption of commercials (Wood; Baughman, 2012). The scarce interaction of the administrators with the public confirms the dominant position of the networks vis-à-vis the Internet (Siapera, 2004).

The unofficial environment, in contrast, is more committed to interactivity. However, although certain sites include their own material, such as interviews with actors, many pages revolve around the official microsite, from where an important part of the sticky content created by the networks for distribution originates (Jenkins; Ford; Green, 2013, p. 4).

With regard to the social buzz, messages tend to be positive and brief evaluations coexist alongside discursive comments. They praise the program, highlight the human values transmitted, show their interest in storylines that deal with important social issues, and value the informative nature of series set in the past. Comments also contribute to the construction of a good reputation, highlighting the quality of the program, the work of the technical team, and the innovation. The promotion of events involving actors and actresses, emotional farewells of the program or characters, and the anger caused by scheduling changes similarly demonstrate the relationships between fans and the program.

The analysis carried out here confirms the four hypotheses put forward in the first part of the article and highlights that, in general, a program's promotional discourse fits into a wider strategy: "the generation of interchange and sociability" (Cogo; Dutra-Brignol, 2011, p. 75). With the same aim, actresses very often relate comments aimed at promoting the program through their personal experiences during filming or their thoughts on a particular scene or storyline.

\section{The fact that only $0.1 \%$ of the comments posted by female users concern censor- ship by the administrators confirms the generalized adoption of netiquette pro- tocols by female fans}

This research is aligned with those studies interested in examining the fans' role as TV shows' promoters on the Internet (Martens, 2011). Text data mining techniques have been the main line of action, due to their capacity to explore wide volumes of online data, even though they are not completely accurate in analyzing the emotions expressed. On this front, the novel methodology implemented allows us to overcome the limitations related to semantic analysis of emotions through the combination of computational and manual techniques designed to work with medium sized samples. Not only do we understand our methodology as a complement of those that have emerged around big data studies (such as sentiment analysis), but we also believe the future of this field lies in the establishment of interdisciplinary collaborations between experts in communication and researchers in computational studies interested in machine learning. Finally, the use of ethnographic methods (interviews, focus groups, surveys...) would be extremely useful in verifying and reaching a better understanding of the results obtained.

This study, included in a broader investigation into women's reception of Spanish scripted television, examines only the comments signed with feminine names (either their real names or assumed names). Further research is required in order to determine possible similarities or/and differences between the posts signed with feminine and masculine names.

\section{Notes}

1. The complexity of a discursive unit stems from the frequent inclusion of various subject matters in the same message.

\section{Acknowledgements}

This article is part of a larger investigation project entitled "Social construction of women in the television fiction and web 2.0: stereotypes, reception and feedback" (FEM2012- 
33411), funded by the Spanish Ministry of Economy and Competitivity (Government of Spain). This part of the research was developed by the authors of the article and the following researchers and contributors: Beatriz Gómez, Mariluz Sánchez, Belén Granda, Tatiana Hidalgo, Paola Cabrera (researchers); Marc Bellmunt, Germán Muñoz, Lucía Trabajo, Estitxu Garai, Amaia Neracan, Elsa Soro, Karina Tiznado, Carlos Toural (contributors).

\section{References}

Anderson, Chris (2008). The long tail: Why the future of business is selling less of more. New York: Hyperion Books. ISBN: 9781401309664

Askwith, Ivan (2007). Television 2.0: Reconceptualizing TV as an engagement medium. Master thesis. Comparative Media Studies.

http://cms.mit.edu/research/theses/lvanAskwith2007.pdf

Barbrook, Richard (2005). "The hi-tech gift economy". First Monday special issue \#3: Internet banking, e-money, and Internet gift economies.

http://cybra.lodz.pl/Content/1081/issues/issue3_12/barbrook/ index.html

Barkhuus, Louise; Brown, Barry (2009). “Unpacking the television: User practices around a changing technology". ACM Transactions on computer-human interaction, v. 19, n. 3. http://dx.doi.org/10.1145/1592440.1592444

Bordieu, Pierre (1979). La distinction: critique sociale du jugement. Paris: Minuit.

Callon, Michel; Méadel, Cécile; Rabeharisoa, Vololona (2002). "The economy of qualities". Economy and society, v. 31, n. 2, pp. 194-217.

http://dx.doi.org/10.1080/03085140220123126

Chan-OImsted, Sylvia M.; Park, Jung-Suk (2000). "From onair to online world: Examining the content and structures of broadcast TV stations' web sites". Journalism \& mass communication quarterly, v. 77 n. 2, pp. 312-339.

http://dx.doi.org/10.1177/107769900007700207

Cogo, Denise; Dutra-Brignol, Liliane (2011). "Social networks and reception studies on the internet". MatriZes, v. 4, n. 2, pp. 75-92. http://www.matrizes.usp.br/index.php/matrizes/article/ viewFile/75/113

Corujo, Adolfo (2012). “Planeta 2.0. Revoluciones políticas y reputaciones empresariales. La geopolítica y la transformación cultural en las organizaciones van de la mano". In: d+i Llorente \& Cuenca. Innovación y reputación, Madrid: Anatomía de Red, pp. 140-144.

http://www.desarrollando-ideas.com/publico/llyc-innovacionreputacion.pdf

Cronin, Anne (2004). "Regimes of mediation: advertising practitioners as cultural intermediaries?". Consumption, markets and culture, v. 7, n. 4, pp. 349-369.

http://dx.doi.org/10.1080/1025386042000316315

Dayan, Daniel (2001). "The peculiar public of TV". Media culture society, v. 23, n. 6, pp. 743-765.

http://dx.doi.org/10.1177/016344301023006004
Deery, June (2003). "TV.com: Participatory viewing on the web". The journal of popular culture, v. 37, n. 2, pp. 161-183. http://dx.doi.org/10.1111/1540-5931.00062

Evans, Elizabeth (2011). Transmedia television. Audiences, new media and daily life. New York/Oxon: Routledge. ISBN: 9780415882927

Gauntlett, David (2000). "Web studies: A user guide". In: Gaunlett, David. Web studies. Rewiring media studies for the digital age. New York: Oxford University Press, pp. 2-18. ISBN: 9780340760482

Gillan, Jennifer (2010). Television and new media: Must click TV. New York: Routledge. ISBN: 9780203875032

Gray, Jonathan (2003). "New audiences, new textualities. Anti-fans and non-fans". International journal of cultural studies, v. 6, n. 1, pp. 64-81. http://dx.doi.org/10.1177/1367877903006001004

Jenkins, Henry (1992a). "Strangers no more, we sing': Filking and the social construction of the science fiction fan community". In: Lewis, Lisa A. The adoring audience. Fan culture and popular media. London: Routledge, pp. 208236. ISBN: 0415078202

Jenkins, Henry (1992b). Textual poachers: Television fans \& participatory culture. New York: Routledge. ISBN: 978 0415905725

Jenkins, Henry (1998). The poachers and the stormtroopers: Cultural convergence in the digital age. Conference at MIT Comparative Media Studies. University of Southern California.

http://web.mit.edu/21fms/People/henry3/pub/ stormtroopers.htm

Jenkins, Henry (2006). Convergence culture: where old and new media collide. New York/London: New York University. ISBN: 9780814742952

Jenkins, Henry (2008). "From production to produsage: Interview with Axel Bruns (Part one)". Confessions of an acafan, May $9^{\text {th }}$.

http://henryjenkins.org/2008/05/interview_with_axel_ bruns.html\#sthash.91niVbc1.dpuf

Jenkins, Henry; Ford, Sam; Green, Joshua (2013). Spreadable media: Creating value and meaning in a networked culture. New York: NYU Press. ISBN: 9780814743508

Kinder, Marsha (1992). Paying with power in movies, television, and video games: from muppet babies to teenage mutant ninja turtles. Berkeley: University of California Press. ISBN: 9780520077768

Kjosen, Atle-Mikkola (2011). "Gifts and commodities: Temporal contradictions of the internet economy and their forms of appearance". In: Media in transition 8, pp. 1-13. http://web.mit.edu/comm-forum/mit7/papers/Kjosen_ draft.pdf

Lacalle, Charo (2013). Jóvenes y ficción televisiva. Construcción de identidad y transmedialidad. Barcelona: UOC Press. ISBN: 9788490297049 
Larsen, Peter (2010). "The grey area. A rough guide. Television fans, internet forums, and the cultural public sphere". In: J. Gripsrud (ed.), Relocating television. Television in the digital context (pp. 157-168). New York: Routledge.

Lee, Hye-Kyung (2012). "Cultural consumers as 'new cultural intermediaries': manga scanlators". Arts marketing: An international journal, v. 2, n. 2, pp. 231-143.

http://dx.doi.org/10.1108/20442081211274011

Martens, Marianne (2011). "Transmedia teens: Affect, immaterial labor and user-generated content". Convergence, v. 17, n. 1, pp. 49-68.

http://dx.doi.org/10.1177/1354856510383363

Martínez-Priego, Chema (2009). "Ser un community manager". In: Sanagustín, Eva (ed.). Del 1.0 al 2.0: claves para entender el nuevo marketing. Bubok Publishing, pp. 143152. ISBN: 97899160443

http://uphm.edu.mx/libros/clavesdelnuevomarketing.pdf

McFall, Liz (2012). "The problem of cultural intermediaries in the economy of qualities". In: Smith-Maguire, Jennifer; Matthews, Julian. The cultural intermediaries reader. London: Sage, pp. 42-51. ISBN: 9781446201336

Meso-Ayerdi, Koldo; Mendiguren-Galdospin, Terese; Pérez-Dasilva, Jesús-Ángel (2015). "The role of community manager in the marketing strategies of the Spanish companies most active on social networks". Estudios sobre el mensaje periodístico, v. 21, n. 1, pp. 385-402.

http://dx.doi.org/10.5209/rev_ESMP.2015.v21.n1.49101

Muniz, Albert M.; O’Guinn, Thomas C. (2001). “Brand community". Journal of consumer research, v. 27, n. 4, pp. 412-432. http://dx.doi.org/10.1086/319618

Negus, Keith (2002). "The work of cultural intermediaries and the enduring distance between production and consumption". Cultural studies, v. 16, n. 4, pp. 501-515. http://dx.doi.org/10.1080/09502380210139089

Preece, Jenny; Nonnecke, Blair; Andrews, Dorine (2004). "The top five reasons for lurking: improving community experiences for everyone". Computers in human behaviour, v. 20, n. 2, pp. 201-223.

http://dx.doi.org/10.1016/j.chb.2003.10.015

Ramos, Marina; Lozano, Javier (2011). "Promoting lost. New strategies and tools of commercial communication". In: Pérez-Gómez, Miguel-Ángel. Previously on: Estudios interdisciplinarios sobre la ficción televisiva en la tercera edad de oro de la televisión. Sevilla: Biblioteca de la Facultad de Comunicación de la Universidad de Sevilla, pp. 421-432.
ISBN: 9788469518083

http://fama2.us.es/fco/previouslyon/25.pdf

Ramos, Marina; Lozano, Javier; Hernández-Santaolalla, Víctor (2012). "Fanadvertising y series de television". Revista comunicación, v. 10, n. 1, pp. 1211-1223.

http://www.revistacomunicacion.org/pdf/n10/mesa7/094. Fanadvertising_y_series_de_television.pdf

Russo, Julie-Levin (2009). “User-penetrated content: Fan video in the age of convergence". Cinema journal, v. 48, n. 4, pp. 125-130.

http://dx.doi.org/10.1353/cj.0.0147

Siapera, Eugenia (2004). "From couch potatoes to cybernauts? The expanding notion of the audience on TV channels' websites". New media \& society, v. 6, n. 2, pp. 155-172. http://dx.doi.org/10.1177/1461444804041446

Smith-Maguire, Jennifer (2014). "Bordieu on cultural intermediaries". In: Smith-Maguire, Jennifer; Mattews, Julian, The cultural intermediaries reader. London: Sage, pp. 15-24. http://uk.sagepub.com/sites/default/files/upmbinaries/63872_Maguire_CH1.pdf

Smith-Maguire, Jennifer; Matthews, Julian (2012). "Are we all cultural intermediaries now? An introduction to cultural intermediaries in context". European journal of cultural studies, v. 15, n. 5, pp. 551-62.

http://dx.doi.org/10.1177/1367549412445762

Spottswood, Erin L.; Walther, Joseph B.; Holmstrom, Amanda J.; Ellison, Nicole B. (2013). "Person-centered emotional support and gender attributions in computer-mediated communication". Human communication research, v. 39, n. 3, pp. 295-316.

http://dx.doi.org/10.1111/hcre.12006

Terranova, Tiziana (2000). "Free labor. Producing culture for the digital economy". In: Social text 63, v. 18, n. 2, pp. 33-58. http://web.mit.edu/schock/www/docs/18.2terranova.pdf http://dx.doi.org/10.1215/01642472-18-2_63-33

Vassallo, Maria-Immacolata (2012). "A case study on transmedia reception: Fandom on Facebook and social issues in the Brazilian telenovela Passione". Anàlisi. Quaderns de comunicació i cultura, febr., pp. 111-132.

http://journals.uoc.edu/index.php/analisi/article/view/ m2012-vassallo

Wood, Megan M.; Baughman, Linda (2012). "Glee fandom and Twitter: Something new, or more of the same old thing?". Communication studies, v. 63, n. 3, pp. 328-344. http://dx.doi.org/10.1080/10510974.2012.674618
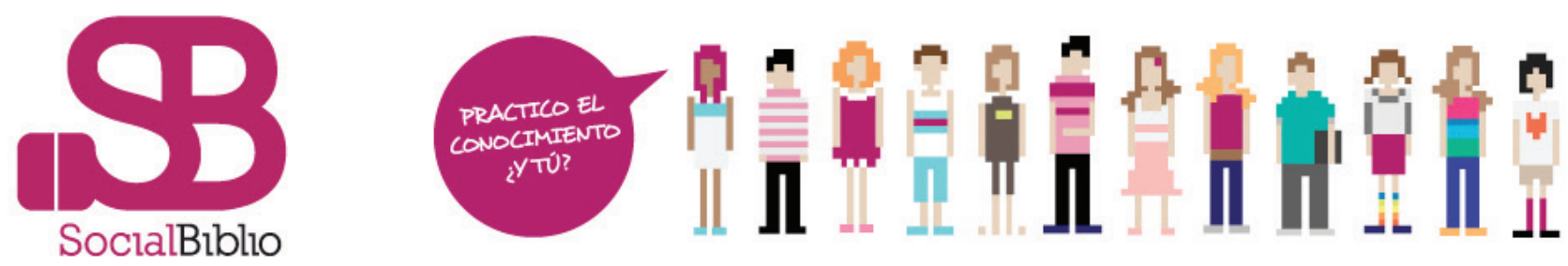